\title{
The system of managing the pedagogical process of training students- specialists in the tourism sector in the conditions of COVID-19
}

\section{O sistema de gestão do processo pedagógico de formação de alunos- especialistas do sector do turismo nas condições do COVID-19}

\section{El sistema de gestión del proceso pedagógico de formación de estudiantes-especialistas del sector turístico en las condiciones del COVID-19}

\author{
Iryna Olenych $^{1}$ (D) Zoriana Gontar $^{2}$ (D), Yuliia Borutska ${ }^{3}$ iD
}

\footnotetext{
${ }^{1}$ Department of Tourism, Lviv State University of Physical Culture named after Ivan Boberskyj, Lviv, Ukraine.

${ }^{2}$ Department of Social Work, Management and Social Sciences, Lviv State University of Security Life activity, Lviv, Ukraine.

${ }^{3}$ Department of Tourism, Lviv National Agrarian University, Lviv, Ukraine.
}

Corresponding author:

Iryna Olenych

Email: omarow998@ukr.net

How to cite: Olenych, I., Gontar, Z., \& Borutska, Y. (2021). The system of managing the pedagogical process of training students-specialists in the tourism sector in the conditions of COVID-19. Revista Tempos e Espaços em Educação, 14(33), e16569. http://dx.doi.org/10.20952/revtee.v14i33.16569

\begin{abstract}
The last few years have seen an increase in competitiveness in many areas of the economy of the developed countries of the world. The only urgent problem is the training of personnel in the field of tourism, in particular during pandemic restrictions. And this problem is more complicated than just a shortage of graduates. Pedagogical training in the field of tourism is a systematic and organized training of qualified specialists in hotels and other accommodation facilities, facilities and means of recreation, public catering, as well as facilities for business, health, sports, and educational purposes. Currently, the market situation is such that graduates of specialized educational institutions do not meet professional requirements that meet international standards. Today's specialists have a low professional level, so hotels and travel companies, which have their own training programs, have to retrain hired employees. Young specialists have insufficient competence and lack of adaptive skills that they should possess in a developed competitive environment. Taking this into account, the purpose of this article is to determine and analyze the features of managing the training of future specialists in the tourism industry in a pandemic. The analysis of the problem was carried out by using traditional methods of analysis and interpretation of statistical and literary criticism with new approaches to analysis, synthesis and abstraction. As a result, the main
\end{abstract}


pedagogical aspects of the educational process management system for the training of future specialists in the tourism sector in higher education institutions were characterized.

Keywords: Education. Future specialists. Pandemic restrictions. Tourism sector. Tourism.

\section{RESUMO}

Nos últimos anos, assistimos a um aumento da competitividade em muitas áreas da economia dos países desenvolvidos do mundo. O único problema urgente é o treinamento de pessoal na área de turismo, em particular durante as restrições de pandemia. E esse problema é mais complicado do que apenas falta de graduados. A formação pedagógica no domínio do turismo é uma formação sistemática e organizada de especialistas qualificados em hotéis e outras instalações de alojamento, instalações e meios de recreação, alimentação pública, bem como instalações para fins empresariais, de saúde, desportivos e educacionais. Atualmente, a situação do mercado é tal que os graduados de instituições de ensino especializadas não atendem aos requisitos profissionais que atendem aos padrões internacionais. Os especialistas de hoje têm um baixo nível profissional, por isso hotéis e agências de viagens, que possuem seus próprios programas de treinamento, têm que reformar os funcionários contratados. Jovens especialistas têm competência insuficiente e falta de habilidades adaptativas que deveriam possuir em um ambiente competitivo desenvolvido. Levando isso em consideração, o objetivo deste artigo é determinar e analisar as características da gestão da formação de futuros especialistas na indústria do turismo em uma pandemia. A análise do problema foi realizada com recurso a métodos tradicionais de análise e interpretação da crítica estatística e literária com novas abordagens de análise, síntese e abstração. Como resultado, foram caracterizados os principais aspectos pedagógicos do sistema de gestão do processo educacional para a formação de futuros especialistas do setor turístico em instituições de ensino superior.

Palavras-chave: Educação. Futuros especialistas. Restrições à pandemia. Setor de turismo. Turismo.

\section{RESUMEN}

Los últimos años han visto un aumento de la competitividad en muchas áreas de la economía de los países desarrollados del mundo. El único problema urgente es la formación de personal en el ámbito del turismo, en particular durante las restricciones pandémicas. Y este problema es más complicado que la escasez de graduados. La formación pedagógica en el campo del turismo es una formación sistemática y organizada de especialistas cualificados en hoteles y otras instalaciones de alojamiento, instalaciones y medios de esparcimiento, restauración pública, así como instalaciones con fines comerciales, sanitarios, deportivos y educativos. Actualmente, la situación del mercado es tal que los egresados de instituciones educativas especializadas no cumplen con los requisitos profesionales que cumplen con los estándares internacionales. Los especialistas de hoy tienen un nivel profesional bajo, por lo que los hoteles y las empresas de viajes, que tienen sus propios programas de formación, tienen que volver a formar a los empleados contratados. Los especialistas jóvenes tienen una competencia insuficiente y carecen de las habilidades de adaptación que deberían poseer en un entorno competitivo desarrollado. Teniendo esto en cuenta, el propósito de este artículo es determinar y analizar las características de gestionar la formación de futuros especialistas en la industria turística en una pandemia. El análisis del problema se llevó a cabo utilizando métodos tradicionales de análisis e interpretación de la crítica estadística y literaria con nuevos enfoques de análisis, síntesis y abstracción. Como resultado, se caracterizaron los principales aspectos pedagógicos del sistema de gestión del proceso educativo para la formación de futuros especialistas del sector turístico en las instituciones de educación superior.

Palabras clave: Educación. Futuros especialistas. Restricciones pandémicas. Sector turístico. Turismo. 


\section{INTRODUCTION}

The Covid pandemic has devastated all areas of economic activity around the world. One cannot but agree with the thesis that this pandemic is: "... the first experience in modern history, when a purely biological factor acquired an almost independent life in the social plane and discovered super-powerful effectiveness in influencing the political, legal, socio-economic spheres, interstate relationships and lifestyles of communities. The coronavirus has become the main effective factor that led to the restructuring of the hierarchy of values under the influence of obvious risks to health and life."(Ratten, 2020)

The Covid pandemic has hit the travel industry extremely hard. You can practically say that the tourism industry has stopped. According to experts, the current tourism crisis can rightfully be considered super-severe in history (Bacq, Lumpkin, 2020). This is confirmed by the following data (Table 1).

As UN Secretary General Antonio Guterres noted in his speech: "... it is so painful to see how the COVID-19 pandemic is devastating the tourism sector." None of the specialists in the field of tourism undertakes to assume when the collapse of the tourism industry will end, because everything depends on the improvement of the situation with the incidence of diseases and the lifting of the ban on movement. At the moment, most countries in the world are only increasing quarantine. Uncertainty regarding the lifting of travel bans predetermines the impossibility of developing tactical and strategic plans for the development of the tourism sector. Even the already upcoming 2021 for tourism enterprises is characterized by complete uncertainty. In the event of a full restoration of all socio-economic processes, the lifting of restrictions, tourist enterprises will have to "work off debts", that is, provide services for the tours postponed from last year.

Table 1. The negative impact of the COVID pandemic on the travel industry. Consequences

The consequences of the painful impact of the COVID pandemic on the tourism sector were manifested in a huge number of interruptions by vacationers of current tours and the cancellation or postponement of planned tours. General tourist flows in the spring "fell" by $100 \%$, and in the summer - by $80 \%$. The latter

1 caused colossal losses for all participants in the tourism market (travel agencies, tour operators, carriers, etc.). According to the WTTC (World Travel and Tourism Council) estimates, in the spring of 2020, the COVID pandemic led to the reduction of up to a million jobs in global tourism. In addition, WTTC experts predict that the scale of losses in the tourism sector of the world could reach more than two trillion. dollars;

the closure of codons, restrictions on movement forced to stop all flights of airlines, and therefore huge financial losses. Not only small low-cost airlines appeared under the threat of bankruptcy, but also the

2 largest European national airlines (example: Lufthansa closed its low-cost airline - Germanwings and reduced the fleet in all subsidiaries, and Virgin Australia - Australia's second largest airline - went bankrupt altogether)

the global cruise industry has also suffered. The ban on movement, stopping tourist flows, negative

3 reputation losses (numerous lawsuits due to the outbreak of coronavirus on board many liners) made it necessary for cruise companies to cancel their flights

4 according to rough estimates of the UNWTO (World Tourism Organization) the crisis caused by the COVID pandemic will "cost tourism up to seven years of growth"

an interesting feature is characteristic of the COVID pandemic - the accompaniment of all epidemiological actions with the so-called "information pandemic" or "pandemic of fear." The latter is associated with the extremely rapid spread and direct influence of information resources on the modern world. Directly influences the planning of all their actions by travelers

To prevent the collapse of the economies, the governments of the countries of the world began to develop and provide large-scale aid packages, namely: the allocation of financial support, the reduction of the tax burden of economic entities and the provision of affordable credit lines for them. This is a significant support, which will allow all market participants to "stay afloat" in the new tough and restrictive economic conditions of operation. Consequently, it is the effective measures 
of state support that largely determine the success of the anti-crisis measures introduced in each country. Also, according to the results of their research, the main anti-crisis steps to overcome the "depressive traps" should be (Awe, Church, 2020):

- restoration of the effective functioning of monetary policy mechanisms to achieve their effectiveness in the process of stimulating economic growth and regulating structural changes;

- improving the sectoral structure of the domestic economy to restore its sensitivity to endogenous factors, will contribute to economic stabilization, adaptation to the structure of domestic demand and optimization of integration into the global division of labor;

- organizational correction of the institutional structure of the domestic economy to consolidate the efforts of society to implement the anti-crisis strategy based on achieving the inclusiveness of the economic development model

What does a graduate of a tourism educational institution lack? First of all, special knowledge and skills, practical experience, knowledge of modern technologies and effective language training. Young specialists have insufficient competence, are not ready to adapt to the competitive environment and make decisions on their own. It is not surprising that the leaders of the industry, travel companies and hotels from year to year say that educational institutions prepare specialists who have not received the knowledge and skills necessary for practical work in an educational institution. With a huge number of graduates of tourist educational institutions today there is an acute shortage of personnel that meet modern requirements.

Travel companies often refuse specialists with diplomas from tourism institutions of higher education, preferring to take graduates with a good language or even technical education. One of the problems that affects the quality of training of specialists is the lack of qualifications of teachers. In the context of the rapid growth in the number of tourist institutions of higher education, many of them do not have a trained professional staff.

Many teachers came to tourism educational institutions, to specialized faculties and departments from other industries. In our deep conviction, a teacher of a tourism institution of higher education, in order to equip a graduate with the most modern knowledge, for example, ecommerce technologies with centralized booking systems (CRS) and global product distribution systems (GDS), must have them himself. At present, retraining of personnel in the field of tourism is carried out either by professional associations or enterprises of the tourism industry, or by the companies themselves. Certified teachers focused on teaching the teaching staff of tourism institutions of higher education are clearly not enough

The success of the development of the tourism industry is determined by the quality of professional training of specialists capable of withstanding competition in the labor market in the field of tourism activities. The author notes that the willingness of young specialists to start work is associated with the experience of industrial relations, which the students mastered during their studies in higher education institutions and undergoing all types of internships and internships. (Weaver, 2019).

The training of tourism specialists in the atmosphere of European and Euro-Atlantic integration absorbs many scientific fields, reflecting the features of their future practical activities. It should be noted that the general theoretical level of training provides students with a fairly complete and holistic understanding of the history of the development of a particular phenomenon, the methodology of its research, allows mastering the basics of practical skills and abilities, that is, it performs a complex task of comprehensive and full-fledged training of professional personnel.

The modern world has become what it is, largely due to the development and intensification of communication means and information technologies, therefore, when analyzing modern processes, we will pay special attention to the problem of communication and problems associated with computerization and the Internet, which also, in fact, plays the role of mass media. Global 
changes, which are sometimes catastrophic, are largely stimulated by the development of communication capabilities and the development of virtual space (Cordeiro, Marques, Costa, 2021).

Based on the relevance of the problem of foreign language professional training of future specialists in the field of tourism, we consider it expedient to conduct a scientific study, the purpose of which is a theoretical and practical analysis of the foreign language training of future specialists in the field of tourism, with an emphasis on key skills and skills of readiness for professional foreign language communication.

\section{METHODOLOGY}

The analysis of the problem was carried out by using traditional methods of analysis and interpretation of statistical and literary criticism with new approaches to analysis, synthesis and abstraction.

\section{RESULTS AND DISCUSSION}

At the stage of development of tourism and hospitality in the world, it is customary to distinguish two approaches to training specialists in this area: traditional and modern. The traditional approach to personnel training is determined by the education system, which includes training within the system of higher professional education, as well as in the system of secondary vocational education, in specialized courses and practice-oriented trainings (Dudka, Chumak, Lytvynenko, Benera, Serhiienko, 2020).

The traditional teaching methods in the world are lectures, seminars, mentoring, and also out-of-the-job teaching methods and on-the-job teaching methods. On-the-job training is a practical focus, a direct link to the production functions of personnel.

Outside the workplace learning methods provide an opportunity for distraction from the workplace situation. This training helps to form new behavioral and professional competencies. These two methods are not mutually exclusive; on-the-job training can be done on-the-job or onthe-job. They complement each other, since learning-by-doing in most cases is combined with learning in educational institutions or other organizations.

Outsourcing and outstaffing can be attributed to the modern approach to training personnel for tourism and hospitality enterprises.

Outsourcing is the transfer of non-key functions to a third-party organization for servicing. Few modern leaders consider the benefits of outsourcing non-essential functions to a more professional service provider. For example, outsource the appraisal and recruitment to recruitment agencies. The combination of independent work and outsourcing is internsourcing.

Outstaffing is a method that contributes to the optimization of certain professional skills, knowledge and experience, is in demand in the execution of both short-term and long-term projects, when it is necessary to increase the flexibility of the process of hiring employees for temporary and seasonal projects.

Outsourcing and outstaffing services are becoming commonplace today. Many owners of organizations and enterprises in the field of tourism and hospitality do not accept employees on the staff, but invite specialists from the provider company to work: they use the services of maids, waiters, housekeepers, cooks, preferring not to register them on the staff.

Training in tourist specialties is often carried out only at the level of theory, although it is far from decisive in this profession. Students are sorely lacking in skills that can be provided by practices, study internships and trainings. Meanwhile, the professional training of managers, specialists in tourism, should be combined on the peculiarities of entrepreneurial activity in the field of travel rating and be based on the principles of pedagogical didactics. It should also emphasize practical skills. 
In general, education is a process and a result of education in the system of scientific knowledge, while education in education is a process and result of education with specific knowledge, skills and abilities, which is not necessary for tourism education.

The protection of protection is a cile-direct process of training and motivation in the interests of the country, the state, the government, it supervises the concept of the appearance of a particular specialist at a certain level by the state.

In our opinion, this is professional competence, which is formed from different blocks of knowledge, skills and tips. Vona solves the following tasks:

- to teach, to educate the viconates socially and economically;

- study, generalization and management of the best examples of witchcraft and foreign affairs in view of professional tourism coverage;

- the development of new methods, having hammered in, the form and systems of training, which will be accepted by the neobchidno and primary methodological base for training personnel who are able to solve the problems of the tourism industry.

L.V. Sakun argues that there are three aspects of professional training that are important for any field of tourism, namely:

1. Fundamental education (knowledge), which is responsible for obtaining knowledge on the curriculum of the specialty;

2. Technical training (knowing how to do it) that hones the skill and develops the skills required for a given specialization;

3. Personal abilities (to know how to be and how to behave), reflecting the personal qualities of a specialist.

It should be noted that an integral part of the professional education of students of higher educational institutions = is practical training, which acts, on the one hand, as a share of professional education in the educational and professional training program for specialists, and on the other hand, as a practical one.

Practice is of great importance for the preparation and formation of a specialist and allows (Jandri, Knox, Besley, Ryberg, Suoranta, Hayes, 2018):

- have the necessary knowledge about modern changes in the state, the ability and skills to accept and search for innovative ways of balanced rationality in future professional activities;

- to identify the skills and abilities of organizational, management activities to ensure labor and technological discipline, the creation of safe working conditions for health;

- make professional decisions taking into account their socio-economic and psychological consequences;

- possess the skills and abilities to apply progressive experience in the organization of management and determine the possible scope, conditions and the totality of the consequences of its adaptation in the unit headed.

Practical training of students begins in the process of theoretical training, when laboratory and practical classes are carried out, problems of a certain production content are solved.

Traditionally, in professional pedagogy, the term "practical training" is used to determine the nature of training as an integral part of vocational education, reflects the patterns, content, methods and forms of organizing the process of forming skills, which is aimed at developing students' ability to qualify production work in the chosen specialty.

When training specialists of various levels, practical training is of great psychological importance, in particular (Yeung, Wong, Chan, 2002):

- the alternation of mental work with physical activity improves blood circulation, improves the muscular system, increases mental performance

- a positive attitude towards work, training can manifest itself as a vital necessity and as an internal need of a person; 
- during work, various analyzers are trained and developed;

- practice becomes a criterion for assimilating knowledge, checking its quality and quantity;

- there is an improvement in professional attention.

In the context of the active development of intercultural contacts, today one of the mandatory requirements for the qualifications of modern specialists is the ability to carry out professionally oriented communication in a foreign language. Each professional must have not only professional knowledge, but also build a strategy of foreign language communication in order to transmit information to the interlocutor, describe phenomena, explain facts and give arguments to obtain the desired effect.

The practical goal in teaching a foreign language is determined by the formation of foreign language communicative competence, that is, the development of the ability to carry out appropriate speech activity, the psychological structure of which includes a number of components, should be taken into account when developing exercises for the formation of foreign language skills.

These include:

- motives (communicative and cognitive needs)

- goals (specific expected result)

- subject (a form of displaying connections between objects and phenomena of reality)

- means and methods (knowledge, skills and abilities of the formation and formulation of thought, where the means is language, and the way is speech).

In addition to the general tasks of practical training in the field of vocational education, there are specific tasks that are formed depending on the qualification level, profession and specialty and predetermine the content of training.

One of the problems of education at the present stage is the lack of highly qualified personnel, the professional level of which would correspond to the level. It is this industry that is paid attention not only to economically advanced countries, but also to developing regions. In our opinion, the above pedagogichna shkola povinna gotuvaty specialist who gliboko ucvidomlyue cvoe value cucpilctvi schodo vihovannya fizichno and pcihichno zdorovogo pidroctayuchogo pokolinnya, cpromozhnogo give cucpilctvu human demokratichnogo cvitoglyadu that will dotrimuvaticya gromadyanckih rights and cvobod, from the Office of the innovative potential of regional development povagoyu tourism stavititsya to traditions, cultures, virospovidan and mov Communication among people Correspondent. We agree with N. Nichkalo's assertion that the education in the system of continuous professional education, the co-operation of higher educational institutions and the development of human resources in the development of human resources, starts with the new ones.

The analysis of the peculiarities of training specialists in sports and health tourism in higher educational institutions shows that the existing training system, including curricula and programs for disciplines, does not take into account the specifics of the professional training of a highly qualified specialist to work in the field of sports and recreation activities. The priority directions for the implementation of these tasks are: updating the mission of the education of tourist coverage, the demand for effective pedagogical technologies, the creation of a reading system for methodological and informational support of the school; ensuring the health and safety of vistoy and professional mobility of vypuskniki in higher educational institutions on the labor market through the path of integration of higher educational institutions of different levels of accreditation, scientific institutions and educational institutions; Requests for flexible educational programs and information learning technologies (Tuncay, Keser, Uzunboylu, 2010)

The training of specialists in sports and health tourism should be guided by the peculiarities of tourism activities in general, and sports and health tourism in particular. An important component of work in the field of social and economic policy of the country is the further development of sports and health tourism. Sports and health tourism is an independent and socially 
oriented sphere, a way of life for a significant stratum of society; an effective means of spiritual and physical development of a person; fostering a respectful attitude towards nature, mutual relations and mutual respect between peoples and nations. Social sports and health tourism as a priority area of state support in recent years has begun to cover broader socially vulnerable groups of society: people with disabilities, orphans, families with low monetary incomes, children and adolescents, youth and families in general. In the world practice of tourism development, sports and health tourism is a unique social phenomenon. The phenomenon of this mass sports movement is that with minimal state support, it can successfully exist in today's difficult economic conditions.

The basic principles and directions for the development of sports and health tourism should be (Hinch, Butler, 2007):

- creation of an integral system of interaction between man and the natural environment of his habitat, which allows to harmoniously solve the problems of improving the health of the population and preserving nature by means of sports tourism;

- the allocation, first of all, of mass tourist activities of a pedestrian and competitive nature for children and youth, actively using the natural environment of the most accessible and traditional tourist regions of the country;

- consolidation of actions of executive and legislative authorities at all levels, including selfgovernment bodies, organizations, public associations and citizens for the development and implementation of comprehensive programs aimed at the development of sports and health tourism;

- the interdepartmental principle of management and development of sports tourism, allows to include all age and social groups of the country's population: children, schoolchildren, students, orphans, people with disabilities, etc., as well as the family as a whole, as an alternative to the existing today in the departmental a management system in which, for example, family tourism sites are not located, as one of the natural and effective technologies of a healthy society;

- a well-thought-out and balanced security system during excursions, hikes, personnel training and other events of a sports and tourist nature;

- maximum coverage of the most massive stratum of potential lovers of travel at the place of residence, work and rest, that is, where the issue of prevention of drug addiction, alcoholism and crime is acutely raised;

- using the possibilities of sports tourism to solve a large number of socially useful and applied tasks accompanying the implementation of the goals of the movement and interests that are in the sphere of other ministries and departments, including for using the possibilities of sports and health tourism in the development of extreme tourism in the country ( tourism strategy and tactics, experienced guides and instructors, catalogs of routes and natural objects, new equipment, etc.) (Wang, 2008).

The development of the physical, mental qualities of a person, his social and spiritual health can be ensured by using the means of physical education and physical culture and health-improving work. At the present stage, the specificity of personnel training lies in the fact that there is an intersection of tasks, goals and needs of the commercial tourism infrastructure (training of guides, including for extreme and adventure tours) of the rescue system of the Ministry of Emergency Situations (training of rescuers) of the education system (training teachers of sports tourism in higher educational institutions); administrative tourism infrastructure (training of directors of tourist clubs, employees of tourist regional government agencies, tourist employees of national and natural parks), municipal authorities (training of tourist organizers).

The specificity of the professional dialectic of a specialist in sports and health tourism is beneficial in the fact that (Ageeva, 2002):

1) sports and recreation activities are directed towards the formation of a healthy way of life, mental and physical health; 
2) cportivno-ozdorovchogo tourism specialist should be lyudinoyu, not only do zdatnoyu Organizations for turictckih pohodiv, rozvyazannya tehnichno tactical problem cportivno ozdorovchogo-tourism, but do vikonannya pedagogichnoi, pcihologichnoi, yuridichnoi, geologichnoi, doclidnitskoi, medichnoi diyalnocti;

3) a specialist in sports and health tourism has a vikonovaty priestly-korisna diyalnist (historical, local history, patriotic, health-giving).

All this confirms the neobhidnist definition of the yogo new function of prophylaxis of diiality - physical culture-sports-tourism, straightened to the physical development of a person, preserving his health, rewarding.

However, there are still many shortcomings in the system of training specialists: insufficient attention is paid to practice, few specialists read special courses on tourism, there are no special courses in foreign languages for the tourism sector. All these shortcomings have an explanation, because this industry is new, in the process of formation, the proper experience and traditions have not been formed (Faruk Seyitoğlu, Birsen Çevik, 2016).

There is a need for specialist teachers and teaching aids. All this bears a pronounced economic connotation, because the country is experiencing an acute shortage of financial investment. All the more necessary is the need for domestic scientists, specialists, teachers, publishers. It is necessary to pay attention to Europe, developed in the tourism sector, European countries have already passed a thorny path in creating their own national tourism education

The analysis of programs in academic subjects of the cycle of natural science and general economic and the cycle of professional training, industrial training of students in the specialty 5.03070101 "Tourism services" of the educational qualification level "junior specialist" of universities of I-II levels of accreditation and analysis of the literature allows us to conclude that the system of knowledge and skills, which is used in them, does not take into account the overall objective logic of the formation of professional skills, this is manifested in the following (Zagonari, 2009):

- the majority of professionally oriented disciplines fixed in the programs of connections do not always provide the basis for a logical connection between theoretical and practical training;

- most professionally oriented subjects contribute to the formation of professional knowledge, techniques, ways of action, but are not included in the integral system of professional skills as its organic component;

- part of the knowledge in the educational process is aimed at expanding the general outlook of students, but does not contribute to the formation of professional skills of future specialists.

This fully confirms the opinion of specialists who today state the inadequacy of the training of tourism business specialists to modern social requirements, show a gap between the real preparedness of a graduate and those needs that are put forward by society to the level of their professional training.

We agree with A.A. Degtyarev that the reasons for this are the lack of the necessary set of State educational standards for higher education from the new direction "Tourism" - this does not allow for more efficient and high-quality training of specialists for the tourism business; imperfections in the forms and methods of organizing the educational process; poor practical training of students (Barron, Maxwell, 1993).

In order to improve the practical training of students in the specialty 5.14010301 "Tourist services" of the educational qualification level "junior specialist", the College of Technologies and Design of Lugansk National Taras Shevchenko University is working on the introduction of innovative teaching technologies. In particular, the technology "Learning by doing" - training with the simultaneous execution of production tasks and operations at specific workplaces - allows you to combine the assimilation of theoretical knowledge and the formation of skills and abilities, gives a greater effect compared to traditional methods of presenting educational material (lectures, 
seminars). The main factor of success when using "Learning by doing" technologies is the active role of students in assimilating educational material and mastering professional skills (Amalu, Ajake, Oba, Okpara, 2012).

In the context of this technology, work has begun on the creation of an educational travel agency, which will ensure that not only practical classroom studies are conducted as part of the study of disciplines in the course of study, but also the successful conduct of educational practice in order to form professional skills in performing production tasks at specific workplaces. Simulation technology allows you to model the internal environment of an organization, taking into account modern requirements for personnel, technology, structure and culture of the organization, it is modeled, determined by the mission and objectives of its activities and the tasks of a specific field of activity. Therefore, imitation of students' activities in the conditions of a training travel agency will not only provide knowledge on specific issues of organizing activities, but also allow students to adapt easier and faster in normal conditions after graduation (when creating their own business or when applying for a job in an existing organization).

One of the activities of the simulation firm is the organization and conduct of an educational fair, which is an outstanding, bright, emotionally intense and professionally oriented event of the educational process, one of the main methods and forms of practical training for students (Aksu, Köksal, 2005).

So, with the rapid development of tourism in the world, the labor market is becoming more and more demanding of specialists, whose training should take place at a high level of theoretical and practical training. An important change is the spread of the coronavirus pandemic, which was a watershed moment in the functioning of the tourism industry.

That is why the organization of effective practical training provides an opportunity to apply your knowledge in practice and help young professionals get a job.

\section{CONCLUSION}

Thus, taking into account the above, it can be argued that the training of specialists in conditions of study in a higher education institution is a strategically important aspect. A tourism specialist needs systemic knowledge, a balanced approach in the ratio of theoretical and practical training, a high level of development of general and professional competencies, an understanding that the hotel and restaurant industry is a complex socio-economic mechanism.

We believe that the most significant factors in improving the quality of training for tourism specialists are: their theoretical training with the simultaneous development of entrepreneurial skills; development and formation of scientific and methodological support; students' practical training in service organizations in various sectors of the economy; psychological support for professional training of students in an educational institution; introduction of innovative teaching methods into the educational process

The system of training personnel for the tourism sector should be multifaceted, harmonious, flexible, mobile, so that as soon as possible it is able to respond to any changes in the tourism market, be able to successfully restructure and contribute to the tourism sector becoming one of the most profitable sectors of the national the economy.

Authors' Contributions: Olenych, I.: conception and design, acquisition of data, analysis and interpretation of data, drafting the article, critical review of important intellectual content; Gontar, Z.: conception and design, acquisition of data, analysis and interpretation of data, drafting the article, critical review of important intellectual content; Borutska, Y.: conception and design, acquisition of data, analysis and interpretation of data, drafting the article, critical review of important intellectual content. All authors have read and approved the final version of the manuscript.

Ethics Approval: Not applicable. 
Acknowledgments: Not applicable.

\section{REFERENCES}

Ageeva V, (2002) Male pseudonym and female independence (an attempt by gynecritics) Three destinies of Marko Vovchok in Ukrainian, Russian and French literature: anthology / comp. V. Ageeva. Kiev: Fact, 103-113.

Aksu, A., \& Köksal, C. (2005), Perceptions and attitudes of tourism students in Turkey. International Journal of Contemporary Hospitality Management, 17(5), 436-447. https://doi.org/10.1108/09596110510604869

Amalu, T., E., Ajake A., Oba, D., \& Okpara D. E. (2012). Assessment of the influence of education on tourism development in Enugu State, Nigeria. American Journal of Tourism Research, 1(1), 33-42. https://doi.org/10.11634/216837861403127

Awe, O. A., \& Church, E. M. (2020). Project flexibility and creativity: the moderating role of training utility. Management Decision, Ahead-of-print No. ahead-of-print. https://doi.org/10.1108/MD-02-2020-0226

Barron, P., \& Maxwell, G., (1993), Hospitality management students' image of the hospitality industry. International Journal of Contemporary Hospitality Management, 5(5), p. 5-8.

Bacq, S., \& Lumpkin, G. T. (2020). Social Entrepreneurship and COVID-19. Journal of Management Studies, 51(1), 285288. https://doi.org/10.1111/joms.12641

Cordeiro, E. P. B., Marques, M. M. C., \& Costa, M. T. N. (2021). Socio-emotional education: paths to inspire studies, research and practices. Revista Tempos e Espaços em Educação, 14(33), e13729.

https://doi.org/10.20952/revtee.v14i33.13729

Dudka, T., Chumak, M., Lytvynenko, N., Benera, V., \& Serhiienko, T. (2020). Educational systems of Eastern European countries as a subject of international comparative research. Revista Tempos e Espaços em Educação, 13(32), 1-15. https://doi.org/10.20952/revtee.v13i32.14068

Hinch. T., \& Butler, R., (2007), Tourism and indigenous people: issues and implications. Butterworth-Heinemann Publishers, Amsterdam.

https://www.researchgate.net/publication/262688802 Tourism and Indigenous Peoples Issues and Implications

Jandri, P., Knox, J., Besley, T., Ryberg, T., Suoranta, J., \& Hayes, S. (2018). Postdigital science and education. Educational Philosophy and Theory, 50(10), 893-899. https://doi.org/10.1080/00131857.2018.1454000

Ratten, V. (2020). "Coronavirus (Covid-19) and Social Value co-Creation." International Journal of Sociology and Social Policy. DOI: https://doi.org/10.1108/IJSSP-06-2020-0237

Seyitoğlu, F., \& Çevik, B. (2016): The impacts of student and life satisfaction on tourism students' perceived sense of belonging. Journal of Teaching in Travel \& Tourism, 16(4), 253-262. https://doi.org/10.1080/15313220.2016.1197083

Yeung, S., Wong, S., \& Chan, B. (2002). Ethical beliefs of hospitality and tourism students towards their school life. International Journal of Contemporary Hospitality Management, 14(4), 183-192.

https://doi.org/10.1108/09596110210427030

Tuncay, N., Keser, H., Uzunboylu, H., (2010). “If Knowledge is Power Why Keep It Secret?". Procedia-Social and Behavioral Sciences, 2(2), 5650-5658. https://doi.org/10.1016/j.sbspro.2010.03.923

Wang, J. (2008). Is tourism education meeting the needs of the tourism industry? An Australian case study, Dissertation, University of Canberra, Australian Capital Territory, Australia.

Weaver, R. L. (2019). Social Enterprise and the Capability Approach: Exploring How Social Enterprises Are Humanizing Business. Journal of Nonprofit \& Public Sector Marketing 32 (5), 1-26.

https://doi.org/10.1080/10495142.2019.1589630

Zagonari, F. (2009). Balancing tourism and training. International Journal of Hospitlaity Management 28, 2-9. https://doi.org/10.1016/j.ijhm.2008.03.006

Received: 31 July 2021 | Accepted: 14 October 2021 | Published: 5 November 2021

This is an Open Access article distributed under the terms of the Creative Commons Attribution License, which permits unrestricted use, distribution, and reproduction in any medium, provided the original work is properly cited. 